\title{
Risk factors for involvement in cyber bullying: Victims, bullies and bully-victims
}

\author{
Faye Mishna, Mona Khoury-Kassabri, Tahany Gadalla, Joanne \\ Daciuk
}

Version Post-print

Citation Mishna, F., Khoury-Kassabri, M., Gadalla, T. \& Daciuk,

(published version) J., Risk factors for involvement in cyber bullying: Victims, bullies and bully-victims,

Children and Youth Services Review (2011), doi:

10.1016/j.childyouth.2011.08.032

Copyright / License CC BY-NC-ND 


\section{TSpace Research Repository}

\section{tspace.library.utoronto.ca}

Always cite the published version, so the author(s) will receive recognition through services that track
citation counts, e.g. Scopus. If you need to cite the page number of the TSpace version (original manuscript or
accepted manuscript) because you cannot access the published version, then cite the TSpace version in
addition to the published version using the permanent URI (handle) found on the record page. 


\section{Accepted Manuscript}

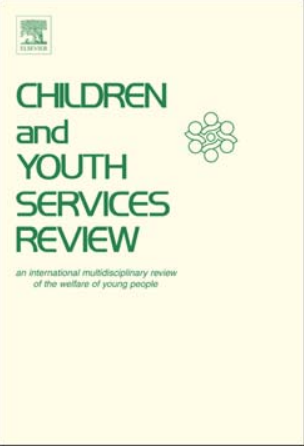

PII:

DOI:

S0190-7409(11)00334-3

Reference: $\quad$ CYSR 1716

To appear in: $\quad$ Children and Youth Services Review

Received date: 29 June 2011

Revised date: $\quad 24$ August 2011

Accepted date: $\quad 29$ August 2011

Please cite this article as: Mishna, F., Khoury-Kassabri, M., Gadalla, T. \& Daciuk, J., Risk factors for involvement in cyber bullying: Victims, bullies and bully-victims, Children and Youth Services Review (2011), doi: 10.1016/j.childyouth.2011.08.032

This is a PDF file of an unedited manuscript that has been accepted for publication. As a service to our customers we are providing this early version of the manuscript. The manuscript will undergo copyediting, typesetting, and review of the resulting proof before it is published in its final form. Please note that during the production process errors may be discovered which could affect the content, and all legal disclaimers that apply to the journal pertain. 
Running Head: Cyber Bullying Behaviors

\title{
Risk Factors for Involvement in Cyber Bullying: Victims, Bullies and Bully-Victims
}

\author{
Faye Mishna, Ph.D. \\ Factor-Inwentash Faculty of Social Work, University of Toronto
}

Mona Khoury-Kassabri, Ph.D.

School of Social Work and Social Welfare, the Hebrew University of Jerusalem

Tahany Gadalla, Ph.D.

Factor-Inwentash Faculty of Social Work, University of Toronto

Joanne Daciuk, B.A., B.Ed.

Factor-Inwentash Faculty of Social Work, University of Toronto 
Correspondence should be addressed to Faye Mishna, University of Toronto

Factor-Inwentash Faculty of Social Work, 246 Bloor Street West, Toronto, Ontario, Canada. E-mail: f.mishna@utoronto.ca

We would like to acknowledge Bell Canada for providing support for this research.

\begin{abstract}
The use of online technology is exploding worldwide and is fast becoming a preferred method of interacting. While most online interactions are neutral or positive the Internet provides a new means through which children and youth are bullied. The aim of this grounded theory approach was to explore technology, virtual relationships and cyber bullying from the perspectives of students. Seven focus groups were held with 38 students between fifth and eighth grades. The participants considered cyber bullying to be a serious problem and some characterized online bullying as more serious than traditional' bullying because of the associated anonymity. Although the students depicted anonymity as integral to cyber bullying, the findings suggest that much of the cyber bullying occurred within the context of their social groups and relationships. Findings revealed five major themes: technology embraced at younger ages and becoming the dominant medium for communication; definitions and views of cyber bullying; factors unique to cyber bullying; types of cyber bullying; and telling adults. The findings highlight the complexity of the perceived anonymity provided by the Internet and how
\end{abstract}


this may impact cyber bullying. The study offers greater awareness of the meanings of online relationships for children and youth.

Keywords: cyber bullying; focus groups; bullying; online bullying; online relationships;

children and youth 
Ongoing and Online: Children and Youth's Perceptions of Cyber Bullying

\section{Introduction}

The exponential growth of electronic and computer based communication and information sharing during the last decade has drastically altered individuals' social interactions, learning strategies and choice of entertainment. In particular, there is a rapid rise of social networking on the Internet created by the growing access and use of electronic communication tools such as email, websites, instant messaging, webcams, chat rooms, social networking sites, blogs, and text messages (Hinduja \& Patchin, 2009; Palfrey \& Gasser, 2008; Schrock \& Boyd, 2008). Indeed it has been suggested that the majority of youth view these electronic communication tools as eritical tools for their social life" (Kowalski, Limber, \& Agatston, 2008, p. 2). The Internet provides innumerable possibilities for growth among children and youth, including benefits such as social support, identity exploration, and development of interpersonal and critical thinking skills, as well as educational benefits generated from expansive access to knowledge, academic support, and worldwide cross-cultural interactions (Gross, 2004; Jackson, von Eye, Biocca, Barbatsis, Zhao, \& Fitzgerald, 2006; Valkenburg \& Peter, 2007). Although most of the interactions are considered positive or neutral, more recent attention has focused on understanding cyber risks and the potential for abuse as youth spend more time online than ever before (Mitchell, Finkelhor, \& Wolak, 2003; Shariff, 2009).

Although traditional bullying has long been considered a school-based problem (Craig \& Pepler, 2008), electronic communication tools are moving the discussion of bullying into the realm of the electronic information highway. Similar to traditional bullying, cyber bullying, also known as electronic bullying or online social cruelty (Kowalski et al., 2008), includes willful and repeated harm inflicted" (Hinduja \& Patchin, 2009, p. 5) towards another. What makes 
cyber bullying distinct is the use of electronic communication technology as the means through which to threaten, harass embarrass, or socially exclude (Hinduja \& Patchin, 2009; Patchin \& Hinduja, 2006; Williams \& Guerra, 2007). Cyber bullying can encompass the use of an electronic medium to sexually harass (Hinduja \& Patchin, 2008; Shariff \& Johnny, 2007), including distributing unsolicited text or photos of a sexual nature or requesting sexual acts either online or offline (Schrock \& Boyd, 2008). There has been a recent spike in the academic literature devoted to this new form of bullying (Berson, Berson, \& Ferron, 2002; Hinduja \& Patchin, 2009; Lenharrt, 2007; Mitchell et al., 2003; Wolak, Mitchell, \& Finkelhor, 2006; Ybarra $\&$ Mitchell, 2004a,b) including large surveys to determine normative data on the prevalence and character of cyber bullying.

In this paper we add to the growing body of literature by exploring the perspectives of students in grades 5 through 8 (10-13 years) in a large urban centre to provide indepth views of cyber bullying. Qualitative inquiry provides a research design capable of discovering important discourses and nuances of cyber bullying that might be less visible in large scale studies. This is especially important given that previous research has suggested that children may be unlikely to speak about sensitive issues such as harassment and bullying (Dehue, Bolman \& Vollink, 2008; Slonje \& Smith, 2008). Livingstone and Haddon (2008) further argue that tess research is qualitative or multi-method in nature, so we have less knowledge of children's own experiences or perceptions, or of the ways in which online activities are contextualized within their everyday lives" (p. 317).

\section{Cyber Bullying}

The prevalence rates of cyber bullying typically range across studies from approximately 10 to 35 percent (Agatston, Kowalski \& Limber, 2007; Hinduja \& Patchin, 2008; Kowalski \& 
Limber, 2007, 2008; Li, 2007; Patchin \& Hinduja, 2006; Williams \& Guerra, 2007), whereas others have found significantly higher rates (Juvonen \& Gross, 2008; Raskauskas \& Stoltz, 2007). Research provides a picture of the significant psychosocial and academic effects of cyber bullying. Students who were cyber bullied reported feelings of sadness, anxiety, and fear, and an inability to concentrate which affected their grades (Beran \& Li, 2005). Youth who were bullied online were more likely to have skipped school, to have had detentions or suspensions, or to have carried a weapon to school (Ybarra, Diener-West, \& Leaf, 2007). Depression, substance use and delinquency are significantly higher among youth who report experiencing cyber bullying (Mitchell, Ybarra, \& Finklhor, 2007). Evidence reveals that youth who perpetrate cyber bullying are more likely to concurrently engage in rule-breaking and to have problems with aggression (Ybarra \& Mitchell, 2007). Kowalski and Limber (2008) surveyed over 900 students in grades 6 to 12 and found that students who both bullied and were victimized in the previous two months were more anxious, depressed and had lower-self-esteem than other students.

A large proportion of children and youth do not disclose their experiences of cyber bullying to their parents ( $\mathrm{O}^{\prime} \mathrm{C}$ connell, Price, \& Barrow, 2004). This troubling finding corresponds with the stable results that a significant percentage of children who are bullied through traditional methods do not tell adults (Hanish \& Guerra, 2000; Mishna \& Alaggia, 2005). The purpose of this study was to gain understanding of children and youths` views of cyber bullying and of factors that either helped or hindered telling parents and other adults.

\section{Methodology}

Grounded theory was selected as it provided a framework to inductively explore children and youth's perceptions and opinions regarding cyber bullying (Glaser, 1978; Strauss \& Corbin, 
1998). Given the dramatic growth of children and adolescents ' use of online technologies for social connections and the relative lack of knowledge about cyber bullying, a grounded theory approach was deemed most appropriate to allow participants ' perspectives to emerge and to explore the complexity of this phenomenon. Focus groups are an innovative approach to understanding children and adolescents' experiences, and have been defined as a -earefully planned discussion designed to obtain perceptions on a defined area of interest in a permissive, nonthreatening environment" (Kruger 1994, p. 6). Unlike interviews, focus groups with children remove the emphasis of the adult-child relationship in data collection methods (Heary \& Hennessy, 2002) by providing children of similar ages the opportunity to share their experiences and perceptions among their peers. Horner (2000) suggests that children are more relaxed and willing to share perceptions when discussions are held with a group of peers" (p. 510). The present study received ethics approval from the University of Toronto Research Ethics Board and from one school board's External Research Review Committee. The second school board accepted the approval of the university and the first school board.

\section{Participants}

Students who were in grades 5 through 8 and who self-identified as regular Internet users were recruited to participate, from five schools within two urban school boards. Approval was obtained from the Boards of Education to conduct focus groups during school hours. Schools were purposively selected from each of the four geographical regions/quadrants of the city in which the larger school board is divided; northeast, northwest, southeast and southwest. Once potential schools were identified, principals were contacted by letter inviting them to participate followed by a telephone call. In schools for which principals gave consent to participate, the research team made presentations to teachers and students in the identified grades, during 
assemblies and staff meetings. Each student was then given an package with information and consent forms to take home. The parents of each student that participated in the study provided written informed consent, after which assent was obtained from the participating student.

\section{Data Collection and Analysis}

The research team was involved with relevant stakeholders for several months in preparation for and during the time the focus groups were conducted. An advisory committee was established comprising representatives from the school boards, which included guidance counsellors, safe school team members, social workers, psychologists, and information technology personnel. This committee helped to develop the questions and to identify schools to be included in the research.

The facilitators included a Ph.D. student who was a school social worker with several years of experience, a Ph.D. student with several years of experience, and a Master of Social Work student who received training to co-lead focus groups. The children were asked to maintain confidentiality within the focus group. Each focus group lasted approximately one hour. Some questions were asked to determine participants' opinions about the frequency with which children and youth use the Internet, cell phones and other forms of communication technology. The students were asked about their views of cyber bullying, for example how often it occurs, what forms it takes, who does the bullying, who is bullied, who knows, and whether and who they tell. Participants were not asked about their own experiences of cyber bullying, in order to protect their confidentiality in the groups. The students were not asked potentially sensitive questions about Internet behaviours in reference to their peers in order to promote openness in the group setting and to lessen the tendency for socially desirable responses (Morgan, 1998). A semi-structured template was developed. Following the constant comparative method (Creswell, 
1998), the interview guide was updated upon completion of each focus group and before the subsequent group. This entailed the principal investigator listening to the audio files after each session, making notes based on the children's responses, and revising the template to ensure that the next focus group included questions based on participants' responses.

The focus groups were digitally recorded and transcribed verbatim. Transcripts were anonymized to ensure participant and school confidentiality. Inductive data analysis was conducted using a constant comparative method (Glaser \& Strauss, 1967). Line-by-line review of the transcripts was conducted and first-level codes (descriptors of key components of the focus groups), including in vivo codes (participants' language), were noted in the margins (Charmaz, 2006; Glaser, 1978). Transcripts were inputted into NVivo (Richards, 1999) and coded into interconnecting themes. Codes were tagged to associated segments of text. Then, the investigators reviewed text corresponding to each of the first-level codes. Using focused coding and a constant comparative method (Charmaz, 2006; Glaser \& Strauss, 1967), first-level codes were further refined and organized into categories. Finally, theoretical coding was undertaken to identify higher level codes and relationships among categories, and to ensure category saturation (Charmaz, 2006; Glazer, 1978). Coding discrepancies were resolved by consensus among the three investigators.

Seven focus groups were conducted with 38 students in grades 5-8, comprising 17 boys and 21 girls. The groups were: group 1: $\mathrm{N}=7,3$ boys and 4 girls; group 2: $\mathrm{N}=6,6$ boys; group 3: $\mathrm{N}=4,1$ boy and 3 girls; group 4: $\mathrm{N}=6,6$ girls; group 5: $\mathrm{N}=3,3$ boys; group 6: $\mathrm{N}=5,2$ boys and 3 girls; group 7: $\mathrm{N}=7,2$ boys and 5 girls. Although it has been suggested that focus groups with children should include homogeneous single-sex groups (Hoppe et al., 1995) using mixed gender groups has resulted in some of the richest findings due to the differences in opinions and 
experiences of boys and girls (Davis, \& Jones 1996; Heary \& Hennessy 2002). Since the focus was not the children's personal experiences it was believed the groups could be either mixed or same gender.

\section{Results}

Using qualitative methodology, this study explored students ${ }^{6}$ views of cyber bullying. The results provide rich understanding of cyber bullying from the students ' perspectives and correspond with research findings in the literature. Themes that emerged in this study include technology embraced at younger ages and becoming the dominant medium; participants“ definitions and views of cyber bullying; factors unique to cyber bullying; types of cyber bullying; and telling adults.

\section{Technology Embraced at Younger Ages and Becoming the Dominant Medium}

The participants were adamant that the age at which children use the Internet and other communication technology is becoming younger and younger." They offered as evidence their own experiences and observations of their younger siblings. For example, one boy expressed concern that his four year old brother -already plays games on the Internet." Even the grade five students, representing the youngest age group in our sample were adept with communication technologies and articulated the benefits and dangers. All the students reported that they and their peers spend a minimum of three hours on their computers daily, after school and maintained that children spend more time on the computer than they do watching television. Some commented that they know tots" of children (themselves included) with both a computer and television in their bedroom and that they often talk to friends on MSN while watching television. 


\section{Definitions and Views of Cyber Bullying}

The participants all defined cyber bullying as a form of bullying which they compared to _traditional' bullying. Some forms of cyber and traditional bullying which they considered similar included spreading rumors, and making threats and derogatory comments. One 10 year old girl for instance, exclaimed, -eyber bullying oh my god! It's another way to bully just over the computer. Some people do cyber bullying as a joke and don't know what it feels to be bullied." Many participants emphasized that it is not just the -big bullies" who engage in bullying others online and that individuals who might be too timid to bully others in real life" might do so in the virtual world. These students talked about the Internet providing anonymity, which they believed fostered bullying by some children who would not otherwise bully.

Several participants emphasized that in cyber bullying situations, children were often at home in their room with the expectation of safety, which was especially distressing. For instance, a 10 year old boy said, -You can`t physically hurt somebody through cyber bullying, but you can definitely hurt your feelings. You can say many hurtful things and make you feel really sad, because you 're in your own safe place. You're in your home."

Most students stated that bullying now can happen all day since technology has extended _schoolyard bullying' to home computers and cell phones, making it possible for -non-stop bullying." When discussing the frequency of cyber bullying participants used terms such as spreading," -everywhere technology is," and as widespread as computers." Most expressed concern about the frequency and considered cyber bullying a serious problem that could cause damage. As one 10 year old boy explained, $\Psi$ think cyber bullying is much worse than verbal bullying because you can't tell anyone about it and then no one really knows what's going on and, the person who's doing it doesn't feel as guilty because they're not saying it to their face." 
Similarly, a girl in grade eight (13 years) thought -eyber bullying is easier to hide. You don't have to talk to the face, so it's easier for the person that bullies, but it's pretty much the same."

Although many participants asserted that cyber bullying was a problem, some boys did not agree. For example, one 13 year old boy asserted, $\Psi$ don't really think it's that big of a problem. It could become a big problem but I don't think at the moment it's a huge problem." Another 13 year old boy stated, Inever thought it was such a big problem. I guess it must be because you are having a focus group about it. But, otherwise, I don't think generally it is that much of a problem." Although one 13 year old boy thought cyber bullying is kind of rare," he believed it could be serious as evident by his statement, - when it happens it can be really really big and can lead to depression and other things."

\section{Factors Unique to Cyber Bullying}

\section{Everywhere and anywhere}

One child coined the term -norstop bullying" to capture the phenomenon of cyber bullying due to bullying occurring at school and continuing online when the child returns home at the end of the day. According to a number of participants, children expect to feel safe and protected from bullying in their own homes. Consequently the cyber bullying they experience while on the computer at home, and often in their own bedroom, may feel particularly invasive. Most of the students talked about cyber bullying also occurring during the school day. Some children explained that although they are not -permitted" to have cell phones turned on during classes, students find ways around this rule, just as they find ways around parents' email passwords and blocking software. They reported that many students text message each other while keeping the cell phone hidden under their desk and use cell phones in the washrooms. 


\section{Anonymity or perceived anonymity}

The image of the cyber aggressor hiding behind the keyboard," coined by a participant, emerged as a primary theme. Most of the students depicted cyber bullying as anonymous. A number of students stressed that a large part of the power and impact of cyber bullying is a function of cyber space whereby the person who bullies is anonymous, and as one student stated, ean be anyone, even someone next door." The participants explained that anonymity lets individuals behave in ways they might not otherwise and that would not otherwise be tolerated. Some students attributed this power of anonymity to individuals feeling more comfortable in their homes with little fear of repercussions or of being traced, which the students believed enables aggressors to threaten, harass, or denigrate others and to even assume a new persona or character online. For example, a 13 year old girl said, +think cyber bullying is just a different way that you do it. It's not face-to-face. It's easier to say more hurtful comments because sometimes you don't like to say things to people's faces but when you do it for revenge on MSN or something, it might be easier to do because you do not see how much they are hurt by it."

The students articulated effects of the anonymity including: the aggressor's perceived power to harass others without consequence; the unique ways through which bullying can occur afforded by anonymity such as a person's ability to assume a friend's identity through use of passwords; the greater fear experienced by students who are threatened online by someone whose identity is not known to them but who knows their identity; and the reluctance to tell adults about the victimization because of their strong belief that it is not possible to prove the cyber incident or to identify the aggressor.

Analysis of the focus group transcripts however, revealed a discrepancy in the students ${ }^{6}$ expressed beliefs regarding anonymity of the cyber aggressor. Although most of the students 
depicted anonymity as integral to cyber bullying, much of the cyber bullying they discussed appeared to take place within the context of the students' social groups and relationships. The following statement by a 12 year old girl captures the confusion about whether the identity of the cyber aggressor is known to the victimized child: Ithink cyber bullying is so horrible because nobody really knows, like if you're being bullied nobody knows, you don't know who's doing it and it's just so silent and even if you do know who's doing it, you feel really bad, you can't see her, you can't really tell to her face how you feel." Types of Cyber Bullying

\section{Posting, coercing and 'backstabbing'}

Many participants talked about children and adolescents, in particular girls, taking pictures of themselves with webcams, which they post, usually for a friend or boyfriend and typically after varying degrees of coercion. The students added that once posted, anyone can steal the pictures." More specifically, several participants described situations in which a boy typically threatens a girl to take a picture on webcam or otherwise run the risk of having her secrets divulged. In one child's words the threat is, if you don't flash I'll tell your secrets." For instance, a 13 year old boy commented, guys who have threatened girls, they say oh, turn on your webcam` or something and then they will flash or stuff like that and if you don't, they'll tell people that you did this and things like that. It's like blackmail." Another 13 year old girl said, what happened to a friend of mine, they were on MSN and one of the people they thought were friends that was a male, they had told their secrets to and they had friends over and they said, if you don't flash us, we'll tell people your secrets.' So, something like that will make them do it because they don't want people knowing their secrets.” The following statement by one girl, (13 years), illustrates considerable worry about webcams: Ithink a huge problem is the webcams, 
making people flash each other, it‘s really scary and there`s a virus that can come into your computer and the person who has sent you the virus has the power to turn the webcam on and off, so if your computer is in your room, they can watch you sleep and stuff like that."

The participants talked about — bakstabbing" friends online, as articulated by a 12 year old girl: - Et's say you are in a fight with your best friend and she is very mad at you and like she might want to do something to get you back. You think that you can trust her but since it's cyber bullying she could put it on her blog or whatever. You don't know."

\section{Masquerading}

Other methods of cyber bullying the students discussed included concealing one's actions for example masquerading as someone other than oneself by assuming a peer's-typically a friend`s - identity, or posting disparaging pictures while remaining hidden. According to the participants concealing one's identity is usually intended to invoke distress or fear in the victimized child. The participants believed that aggressors concealed their identity in order to bully and increase their power by remaining tidden behind the keyboard." The participants described several stealthy acts as occurring regularly on the Internet, email, MSN, social networking sites and gaming sites. For example, a 12 year old girl commented, -eyber bullying is when bullies already bullied someone, but got in trouble by a teacher, so they want to make it silent, so they go on a computer and they try to be hidden and secretive, but still hurting."

Many participants talked about students cyber bullying their friends, even those considered to be close friends, ' whereby the students masqueraded online as the person. The participants explained that students often give out their passwords to their friends as a sign of the friendship and that friends often use the password to gain access to the student ${ }^{\star} s$ profile and, pretending to be that person, bully others. One boy who was 13 years reported that friends masqueraded as 
him a lot.' Iwill go to my friend's house and go on MSN on their computer and I'll forget to sign off, and they could easily just change my password and people who know someone else`s password can pretend to be them and say terrible things to someone else. Some stuff that happens to me is that my friends would like go and talk to someone that is on my contact list and pretend to be me." Reasons provided by the participants for this behaviour included getting back" at someone with whom the child might be angry. As an example, according to one 10 year old girl, F've heard that sometimes cyber bullying is some friends that are really close to you and they want to get back at you and so you sometimes tell them secrets and they hack into your account and email and say mean things to other people and other people will think it ${ }^{\star} s$ you who did it." Participants emphasized that since children do not tend to suspect their good friend, the perpetrator acts cool as though nothing happened." On the other hand, participants described children attributing their own cyber bullying of others to someone else having accessed their password. This way of cyber bullying is exemplified by the following statement of a 13 year old girl: If you say it in person, then that's you saying it for sure, but if you say it over MSN or something and they tell on you, you can easily just say someone hacked your account or something. It was someone else pretending to be you."

\section{Telling Adults}

The students unanimously depicted adults as oblivious to the cyber world and to the phenomenon of cyber bullying. As one student stated, parents and other adults don't get how it is nowadays." Participants concurred that students do not tell their parents or other adults about experiences of cyber bullying. Prime reasons for not disclosing to parents or other adults were fear that their computer privileges would be taken away and the belief that if they told, adults would not be able to find evidence of the cyber bullying or to identify the aggressor. A 13 year 
old girl explained, -some people that may be cyber bullied, if they do tell their principals, a lot of people will just lie and be like that wasn't me on MSN. That was someone else." Other reasons for not telling adults included wanting to be independent, the fear that telling would exacerbate the cyber bullying or that the adult would advise them to -igore it." One boy, 13 years old, talked about cyber bullying as follows: Even if you tell the teachers, like some, I' $\mathrm{m}$ not saying all bullies, but like sometimes their mom doesn't actually care if they're bad at school, so they won't do anything about it. It happened to my friend, like they told the principal and the principal called their mom and then they're like _oh, my mom doesn't care anyways. ' So they never stop, as much as you tell, as much as you do, nothing will happen to the bully.” Another reason for not telling adults was some students ${ }^{\natural}$ belief that because cyber bullying often occurs off school grounds teachers could not do anything. Other participants however, maintained that even if the cyber bullying happens off school property, the school should and would deal with it.

\section{Discussion}

The purpose of this study was to elicit grade 5 through 8 students' perspectives on cyber bullying. It became evident through analysis of the data that cyber bullying can only really be understood and addressed within the context of the new world of cyber space. Although cyber bullying constitutes an alternate method of bullying, cyber bullying must be examined not only in the context of traditional bullying. Rather, to understand cyber bullying the context of the cyber world must be taken into account. Communication technology emerged as integral to the children's interactions and relationships. The participants characterized themselves as highly dependent on communication technology for interaction and reported spending a great deal of time on a daily basis on their computers and cell phones. These findings correspond with the 
literature, which reveals that young people's use of the Internet is now a preferred pastime over watching television (Hinduja \& Patchin, 2009; Kowalski et al., 2008).

According to the findings, not only are children using technology at rapidly increasing rates, they are accessing this technology at younger ages, which is consistent with results of recent studies. For example, according to an American study involving parents of children between the ages of six months and six years, 21 percent of children under the age of two were reported by their parents to have used a computer while 14 percent of these very young children were reported to use computers on a daily basis (Calvert, Rideout, Woolard, Barr, \& Strouse, 2005). It is imperative that parents, teachers, practitioners, and researchers neither overlook nor underestimate children's knowledge of computers and of the Internet. Underestimating children's frequency of computer usage and the significant meaning of communication technology for children and youth creates a technological gap in knowledge across generations. Such a gap can result in an inability by adults to protect children and youth from the potential dangers of this technology.

Analysis of the focus groups suggested that the perceived anonymity of cyber bullying is unique to this form of bullying. The participants generally characterized cyber bullying as anonymous, with associated profound effects. They stated that the sense of anonymity enabled children and youth to act in ways they might not otherwise such as bullying others online, and keeping their identity hidden while bullying others. According to the participants, the anonymity at times increased the distress of victimized students and served as a barrier to telling parents or teachers about online victimization, believing it was impossible to verify the incident or to identify the aggressor. The students' accounts of the effects of this anonymity mirror the literature, in which anonymity of online communication is described as enabling individuals to 
feel free to act in aggressive and inappropriate ways in the cyber world whereas they might not in the real" world (Hinduja \& Patchin, 2009; Postmes \& Spears, 1998; Postmes, Spears, \& Lea, 1998; Shariff, 2009). Indeed, this perceived anonymity has been characterized as a significant difference between online and traditional bullying (Shariff, 2009; Ybarra \& Mitchell, 2004b).

Although most participants expressed the view that anonymity is integral to cyber bullying a prominent theme that emerged was the participants' uncertainty about whether the Internet and other communication technologies provide actual or perceived anonymity for the aggressor. The data contradicted the students' statements, as it emerged that much of the cyber bullying they described was not anonymous. Rather, the cyber bullying often occurred in the context of their social groups and relationships, for example boyfriend/girlfriend, best ${ }^{`}$ friend, and other friends and classmates. Analysis of the participants' comments revealed that the students often discover the identity of the individual who bullies them online, for instance from others who know about or who witness the bullying, albeit at various lengths of times after the incident. This finding is at odds with the general assumption in the literature that cyber bullying is anonymous (Hinduja \& Patchin, 2009; Shariff, 2009). The findings correspond however with other research in which it was found that 73 percent of the youth participants who had experienced cyber bullying reported that they knew the person who bullied them, whereas only 25 percent of the youth reported not knowing the aggressor (National Children's Home survey, 2005).

Corresponding with the finding that cyber bullying may be perceived but not actually be anonymous, a striking finding was that cyber bullying often occurs within the context of relationships and in the presence of -eyber" witnesses or is communicated to others by the aggressor or witnesses. This theme corresponds with robust findings in the literature on traditional bullying that the majority of bullying incidents occur in the presence of peers (Atlas \& 
Pepler, 1998; O‘Connell, Pepler, \& Craig, 1999) and that the roles peers play are pivotal (Hawkins, Pepler, \& Craig, 2001; O‘Connell et al., 1999).

One way of conceptualizing perceived versus actual anonymity is through consideration of the dual and contradictory relationships of technology and relationships, for example friendships among youth. On the one hand, it is recognized that the Internet is fraught with risk, much of which relates to the anonymity provided by cyber space. On the other hand, technology is used as an adaptive and beneficial communication device to develop and maintain relationships, for example among real life" friends (Blais, Craig, Pepler, \& Connolly, 2008; Valkenburg \& Peter, 2007). Although the communication occurs online, these relationships are considered private, based on a perceived commitment and trust. Findings of the present study highlight the need to concurrently: 1) understand and attend to the importance and meaning of online relationships for children and youth (both those that are only online and those that are also known in real life"); and 2) address the inherent risks in online communication and interactions. For example a child or youth may give a trusted friend a password, without anticipating the risks should the relationship change, such as the friend becoming angry and using this password to perpetrate cyber bullying. What occurs within the context of what a child or youth considers a trusted friendship (for example giving a password or sending a picture) may quickly move into the realm of cyber space/Internet with its potential for immediate, anonymous, widespread and lasting distribution and access. Children and youth therefore need education and support to navigate the complexity of their online interactions with others, including the relationships they develop online that may be anonymous" and their relationships with individuals they know in real life."

The participants almost all stated that children would not approach their parents about experiencing cyber bullying. This finding is consistent with the troubling finding that reported 
traditional bullying underestimates the problem (Hanish \& Guerra, 2000) and with findings that cyber abuse is often not reported to parents or authorities (O`Connell et al., 2004). Although some reasons the participants provided for withholding disclosure of cyber bullying parallel those in the traditional bullying literature such as fear of retaliation and worsening of the bullying or that telling adults would not help (Mishna \& Alaggia, 2005), some of their reasons for withholding disclosure were unique to the cyber world. According to the participants, a primary barrier to telling adults about experiences of cyber victimization was fear that their parents would remove Internet or cell phone privileges, to _protect them “ from online victimization. The participants were adamant that losing computer or cell phone access felt like punishment, as it represents loss of their connection with their social world.

\section{Limitations}

To ensure that researchers do not fall into the technological gap across generations, it is important to elicit the experiences of the children and youth who are at the forefront of these technological advances. Since this study obtained the participants' perspectives of cyber bullying through the use of qualitative methodology, the results cannot be generalized beyond the experiences of the children in this sample, as it is unknown to what extent their perspectives apply to children in different schools or geographic locations. Existing research on cyber interactions and bullying however provides support for the present findings (Beran \& $\mathrm{Li}, 2005$; Mitchell et al., 2003; National Children's Home, 2005). Another limitation is that this research did not elicit the students' own experiences and involvement in cyber bullying. As is advisable in collecting sensitive data in the context of a group, by design the children typically spoke in general terms about cyber bullying and about the experiences of their peers. Further research is required in order to obtain the perspectives of those children and youth who are directly involved 
in cyber bullying either as the aggressor or the victim; such research may benefit from the present findings and might include opportunities for data collection outside of the group context.

\section{Implications for Practice, Policy and Research}

The findings of this study correspond with the literature that documents the integral role of electronic technology for children and adolescents, both as a way of communicating and relating positively and as a means through which they bully and are bullied. An important implication is the need for adults, including practitioners to recognize the importance of cyber interactions for children and youth's socialization. It is also necessary to differentiate children's and youth's use of technology that is neutral or positive from use of technology that is abusive or negative.

The finding that cyber bullying is often not anonymous and occurs among children's friendship and social circles requires further study and demands that prevention and intervention programs address children's social and school contexts. As the results highlight that cyber bullying predominantly occurs within existing social relationships and by known perpetrators, it is important that judicial policy makers incorporate an understanding of peer-to-peer victimization in their prevention and intervention efforts in the field of cyber abuse. While a focus on cyber abuse, exploitation, and solicitation by strangers remains vital, it is important to recognize the harm associated with cyber bullying and cyber sexual victimization within the context of peer groups. Practitioners must recognize the importance of electronic communication for children and youth. In addition, it is essential that practitioners understand the phenomenon of cyber bullying including similarities with and differences from traditional bullying. An important focus must be on facilitating the ability of children and youth to tell their parents and other adults about their experiences of cyber bullying and on helping parents and other adults to respond effectively. 
Further research is required to increase our understanding of the new cyber world. The findings of this study correspond with other recent studies which indicate that cyberspace is providing a new frontier in which bullying takes place. Although the present study sheds some light on the complexity of cyber bullying, issues derived from this study that require further examination include questions related to whether and when cyber bullying is anonymous, the differential effects of cyber bullying in general and of particular forms of cyber bullying, the presence of witnesses and factors that promote and interfere with children and youth telling parents and other adults about cyber bullying. Schrock and Boyd (2008) emphasize that studying cyber bullying is a moving target and therefore research must attempt to keep up to this ever changing phenomenon. Livingstone and Haddon (2008) further comment that -asearch in this field becomes quickly out of date, as the technologies, institutions that promote and manage them and children's own practices all continue to change" (p. 317).

\section{Conclusion}

The UN Convention on the Rights of the Child (UNCRC) (United Nations, 1998) identifies adults as responsible to protect children from all forms of physical and mental violence, injury or abuse. Children's and adolescents' regular and intense involvement in the cyber world and the rapid growth of cyber bullying signal an urgent call to action for prevention and protection of children and youth. Today's young wired generation increasingly relies on the Internet and other forms of technology for entertainment, information, personal help and advice, and importantly for social connection and interactions. It is essential that adults acknowledge, understand and accept the Internet and communication technology as a viable and real means of relating for children and youth in order to provide needed guidance and protection, and to keep children safe. 


\section{References}

Agatston, P., Kowalski, R., \& Limber, S. (2007). Students ‘ perspectives on cyber bullying. Journal of Adolescent Health, 41, S59-S60.

Atlas, R.S., \& Pepler, D.J. (1998). Observations of bullying in the classroom. Journal of Educational Research, 92(2), 86-99.

Beran, T., \& Li, Q. (2005). Cyber-harassment: A study of a new method for an old behavior. Journal of Educational Computing Research, 32(3), 265-277.

Berson I.R., Berson M.J., \& Ferron, J.M. (2002). Emerging risks of violence in the digital age: Lessons for educators from an online study of adolescent girls in the United States. Meridian: A Middle School Technologies Journal, 5(2), 1-32.

Blais, J.J., Craig, W.M., Pepler, D., \& Connolly, J. (2008). Adolescents online: The importance of Internet activity choices to salient relationships. Journal of Youth and Adolescence, 37(5), 522-536.

Calvert, S., Rideout, V., Woolard, J., Barr, R., \& Strouse, G. (2005). Age, ethnicity, and socioeconomic patterns in early computer use. American Behavioral Scientist, 48(5), 590 $-607$.

Charmaz, K. (2006). Constructing grounded theory: A practical guide through qualitative Analysis. London, Thousand Oaks CA: Sage Publications.

Craig, W.M., \& Pepler, D. (2008). Introduction: Understanding and addressing bullying: An international perspective. In D. Pepler, \& W. Craig (Eds.), Understanding and addressing bullying: An international perspective (pp. xix-xxvi). Bloomington, Indiana: Authorhouse.

Creswell, J.W. (1998). Qualitative inquiry and research design: Choosing among five traditions. Thousand Oaks: SAGE Publications. 
Davis, A., \& Jones, L. (1996). Environmental constraints on health: Listening to children's views. Health Education Journal, 55, 363-374.

Dehue, F., Bolman, C., \& Vollink, T. (2008). Cyberbullying: Youngsters‘ experiences and parental perception. Cyberpsychology \& Behavior: The Impact of the Internet, Multimedia and Virtual Reality on Behavior and Society, 11(2), 217-223.

Glaser, B. (1978). Theoretical sensitivity: Advances in the methodology of grounded theory. Mill Valley, CA: Sociology Press.

Glaser, B.G., \& Strauss, A.L. (1967). The discovery of grounded theory: Strategies for qualitative research. Alkine: New York.

Gross, E.F. (2004). Adolescent Internet use: What we expect, what teens report. Journal of Applied Developmental Psychology, 25(6), 633-649.

Hanish, L.D., \& Guerra, N.G. (2000). Children who get victimized at school: What is known? What can be done? Professional School Counseling, 4(2), 113-119.

Hawkins, D.L., Pepler, D.J., \& Craig, W.M. (2001). Naturalistic observations of peer interventions in bullying. Social Development, 10, 512-527.

Heary, C.M., \& Hennessy, E. (2002). The use of focus group interviews in pediatric health care research. Journal of Pediatric Psychology, 27(1), 47-57.

Hinduja, S., \& Patchin, J.W. (2008). Cyberbullying: An exploratory analysis of factors related to offending and victimization. Deviant Behavior, 29, 129-156.

Hinduja, S., \& Patchin, J.W. (2009). Bullying beyond the schoolyard: Preventing and responding to cyberbullying. Thousand Oaks, California: Sage.

Horner, S.D. (2000). Focus on research methods: Using focus group methods with middle school children. Research in Nursing \& Health, 23(6), 510-517. 
Jackson, L., von Eye, F., Biocca, F., Barbatsis, G., Zhao, Y., \& Fitzgerald, H. (2006). Does home Internet use influence the academic performance of low-income children? Developmental Psychology, 42(3), 429-435.

Juvonen, J., \& Gross, E.F. (2008). Extending the school grounds? - Bullying experiences in cyberspace. Journal of School Health, 78(9), 496-505.

Kaynay, J.M., \& Yelsma, P. (2000). Displacement effects of online media in the socio-technical contexts of households. Journal of Broadcasting \& Electronic Media, 44(2), 215-29.

Kowalski, R., \& Limber, S. (2007). Electronic bullying among middle school students. Journal of Adolescent Health, 41, S22-S30.

Kowalski, R., Limber, S., \& Agatston, P.W. (2008). Cyber bullying. Malden MA: Blackwell Publishing.

Kruger, R.A. (1994). Focus groups. A practical guide for applied research (2nd Edition). London: Sage Publications.

Lenhart, A. (2007). Cyberbullying and Online Teens. Pew Internet \& American Life Project, Retrieved online on March 25, 2009 at http://www.pewinternet.org/PPF/r/216/report_display.asp.

Li, Q. (2007). New bottle but old wine: A research of cyberbullying in schools. Computers in Human Behavior, 23, 1777-1791.

Livingstone, S., \& Haddon, L. (2008). Risky experiences for children online: Charting European research on children and the Internet. Children \& Society, 22, 314-323.

Mishna, F., \& Alaggia, R. (2005). Weighing the risks: A child‘s decision to disclose peer victimization. Children \& Schools, 27(4), 217-226.

Mitchell, K.J., Finkelhor, D., \& Wolak, J. (2003). Victimization of youths on the Internet. 
Journal of Aggression, Maltreatment \& Trauma, 8(1/2), 1-39.

Mitchell, K.J., Ybarra, M., \& Finkelhor, D. (2007). The relative importance of online victimization in understanding depression, delinquency and substance use. Child Maltreatment, 12(4), 314-324.

Morgan, D.L. (1998) The focus group guidebook. Thousand Oaks, CA: Sage.

National Children's Home. (2005). Putting U in the picture. Mobile Bullying Survey 2005.

Retrieved online on February 6, 2009:

http://www.nch.org.uk/uploads/documents/Mobile_bullying_\%20report.pdf.

O‘Connell, P., Pepler, D., \& Craig, W. (1999). Peer involvement in bullying: Insights and challenges for intervention. Journal of Adolescence, 22, 437-452.

O‘Connell, R., Price, J., \& Barrow, C. (2004). Emerging Trends amongst Primary School Children's use of the Internet. Cyberspace Research Unit. Full Report. Retrieved online on March 25, 2009:

http://www.uclan.ac.uk/host/cru/docs/emerging trends_full_report_060204.pdf.

Palfrey, J., \& Gasser, U. (2008). Born Digital: Understanding the first generation of digital natives. New York: Basic Books.

Patchin, J., \& Hinduja, S. (2006). Bullies move beyond the school yard: A preliminary look at cyberbullying. Youth Violence and Juvenile Justice, 4(2), 148-169.

Postmes, T., \& Spears, R. (1998). Deindividuation and anti-normative behavior: A metaanalysis. Psychological Bulletin, 123(3), 238-259.

Postmes, T., Spears, R., \& Lea, M. (1998). Breaching or building social boundaries? SIDE effects of computer-mediated communication. Communication Research. Special Issue: (Mis)communicating across boundaries, 25(6), 689-715. 
Raskauskas, J., \& Stoltz, A.D. (2007). Involvement in traditional and electronic bullying among adolescents. Developmental Psychology, 43(3), 564-475.

Richards, L. (1999). Using NVivo in qualitative research. London: Sage.

Shariff, S. (2009). Confronting cyber-bullying: What schools need to know to control misconduct and avoid legal consequences. New York: Cambridge University Press.

Shariff, S., \& Johnny, L. (2007). Cyber-libel and cyber bullying: Can schools protect student reputations and free expression in virtual environments? Mc Gill Journal of Education, 16, 307-342.

Schrock, A., \& Boyd, D (2008). Online threats to youth: Solicitation, harassment, and problematic content: Literature review prepared for the Internet Safety Technical Task Force Retrieved March 25, 2009 online at http://cyber.law.harvard.edu/sites/cyber.law.harvard.edu/files/RAB_Lit_Review_121808_0. pdf

Slonje, R., \& Smith, P. (2008). Cyberbullying: Another main type of bullying? Scandinavian Journal of Psychology, 49, 147-154.

Strauss, A., \& Corbin, J. (1998). Basics of qualitative research: Grounded theory procedures and techniques (Second Edition). Thousand Oaks: Sage.

United Nations (1998). UN Convention on the rights of the child. Retrieved November 22, 2008, from http://www.unicef.org/crc/.

Valkenburg, P., \& Peter, J. (2007). Preadolescents` and adolescents` online communication and their closeness to friends. Developmental Psychology, 43(2), 267-277.

Williams, K., \& Guerra, N. (2007). Prevalence and predictors of Internet bullying. Journal of Adolescent Health, 41(6), S14-S21. 
Wolak, J., Mitchell, K., \& Finkelhor, D. (2006). Online victimization of youth: Five years later. National Center for Missing and Exploited Children, \#07-06-025. Retrieved March 25, 2009 from http://www.unh.edu/ccrc/pdf/CV138.pdf.

Ybarra, M., Diener-West, M., \& Leaf, P. (2007). Examining the overlap in Internet harassment and school bullying: Implications for school intervention. Journal of Adolescent Health, 41, S42-S50.

Ybarra, M.L., \& Mitchell, K.J. (2004a). Youth engaging in online harassment: Associations with caregiver-child relationships, Internet use, and personal characteristics. Journal of Adolescence, 27, 319-336.

Ybarra, M.L., \& Mitchell, K.J. (2004b). Online aggressor/targets, aggressors, and targets: A comparison of associated youth characteristics. Journal of Child Psychology and Psychiatry, 45(7), 1308-1316.

Ybarra, M., \& Mitchell, J. (2007). Prevalence and frequency of Internet harassment instigation: Implications for adolescent health. Journal of Adolescent Health, 41, 189-195. 


\section{Highlights}

- We compare cyber bullying: victims, bullies, bully-victims, no involvement

- We explore the factors that contribute to involvement in cyber bullying.

- One quarter reported involvement as both bully and victim in previous three months.

- In traditional bullying bully-victims represent smallest most vulnerable group

- In the current study the bully-victims category emerged as more common. 